\title{
PKM Pendampingan Guru Madrasah Ibtidaiyah Nurul Mun'im dalam Mengoptimalkan Peran Wali Murid dalam Pembelajaran Daring
}

\author{
Muhammad Ainul Yaqin, ${ }^{1}$ Abd Halim, ${ }^{2}$ Ahmad Zainullah, ${ }^{3}$
} Zainul Badri, ${ }^{4}$ Abdullah ${ }^{5}$

\author{
Universitas Nurul Jadid, Probolinggo 1,2,3,4,5 \\ masainulyaqin@gmail.com ${ }^{1}$, abdhalim2499@gmail.com ${ }^{2}$, zainullaha767@gmail.com ${ }^{3}$, \\ zainulbadri86@gmail.com ${ }^{4}$, dullahmuhammad501@gmail.com ${ }^{5}$
}

Submission: 21/08/2021 Received: 18/09/2021 Published: 31/12/2021

Keywords:

Online Learning,

Covid-19

Katakunci:

Pembelajaran

Daring, Covid-19

\begin{abstract}
The Covid-19 pandemic has changed the order of human life, especially in the field of education. To break the chain of spread of this virus, the government swiftly made a policy in changing face-to-face education into distance education or online (in a network). Online learning is a solution for learning during the Covid-19 pandemic by using technology and internet networks, so it is possible that some obstacles will arise in the teaching and learning process. The purpose of this service is to describe the role of teachers and guardians of students in assisting children's learning during the pandemic. This service method is a qualitative method by describing the problems in online learning assistance. From the results of this service, it can be concluded that online learning is a problem-solving solution for effective learning continuity during the pandemic, the limited supporting infrastructure in online learning is an obstacle during this learning process, one of the benefits of online learning is that students become more independent, teachers are required to create a learning atmosphere more fun and required to master information technology, the role of student guardians is very important in mentoring learning and optimizing online learning activities especially for children aged MI. In online learning, teachers prefer to use WhatsApp groups because they are more accessible to students.
\end{abstract}

\footnotetext{
Abstrak. Pandemi Covid-19 telah mengubah tatanan kehidupan manusia khususnya dalam bidang pendidikan. Untuk memutus mata rantai penyebaran virus ini, pemerintah dengan sigap membuat kebijakan dalam mengubah pendidikan tatap muka menjadi pendidikan jarak jauh ataupun daring (dalam jaringan). Pembelajaran daring merupakan solusi untuk pembelajaran di masa pandemi Covid19 dengan menggunakan teknologi dan jaringan internet, sehingga tidak menutup kemungkinan timbul beberapa hambatan dalam proses belajar mengajar. Tujuan pengabdian ini adalah mendeskripsikan peran guru dan wali murid dalam pendampingan belajar anak selama masa pandemi. Metode pengabdian ini adalah metode kualitatif dengan mendeskripsikan problematika dalam pendampingan pembelajaran daring. Dari hasil pengabdian ini dapat disimpulkan
} 


\begin{abstract}
bahwa pembelajaran daring merupakan pemecahan masalah untuk kelangsungan pembelajaran yang efektif di masa pandemi, terbatasnya prasarana pendukung dalam pembelajaran daring menjadikan kendala saat berlangsungnya pembelajaran ini, salah satu manfaat pembelajaran daring adalah siswa menjadi lebih mandiri, guru dituntut menjadikan suasana belajar lebih menyenangkan dan dituntut untuk menguasai teknologi informasi, peran wali murid sangatlah penting dalam pendampingan belajar dan mengoptimalkan kegiatan pembelajaran daring apalagi untuk anak usia MI. Dalam pembelajaran daring, para guru lebih memilih menggunakan WhatsApp group karena lebih mudah diakses oleh peserta didik.
\end{abstract}

\title{
1 Pendahuluan
}

Pandemi Covid-19 telah menjadi pandemi global dan begitu cepat mewabahnya virus tersebut di dunia termasuk indonesia. Di berbagai negara di dunia bukan hanya sedang mengalami kelemahan ekonomi akibat Covid-19, melainkan juga krisis kesehatan yang berimbas kepada pendidikan. Dewi (2020) berpendapat bahwa pada awalnya penyebaran dari virus Covid-19 sangatlah berdampak pada sektor ekonomi yang menurun, tetapi kini juga dirasakan dalam dunia pendidikan, sehingga pemerintah dan lembaga terkait harus membuat kebijakan untuk memberikan alternatif lain karena tidak bisa lagi melaksanakan proses pendidikan pada lembaga pendidikan.

Menurut berita harian Kompas (2020) setiap negara mempunyai strategi tersendiri dalam menanggulangi pandemi Covid-19 yang dilatarbelakangi kultur budaya dan ekonomi di setiap negara. Ada yang menerapkan lockdown total dan ada juga yang bersifat pembatasan skala mikro, makro dan darurat seperti yang tengah dijalankan pemerintah saat ini, namun dampak dari wabah tersebut juga dirasakan oleh dunia pendidikan. Sesuai dengan pendapat Suriadi et al. (2021) dampak dari pandemi Covid-19 berakibat pada berubahnya situasi dalam kehidupan secara drastis, yang sebelumnya masyarakat dapat hidup secara normal dan saling berinteraksi secara langsung, tetapi saat ini semuanya berubah menjadi serba online terutama dalam dunia pendidikan. Sejalan dengan hal tersebut. Terhitung sudah hampir 2 tahun pandemi Covid-19 melanda tanah air, aktivitas yang semula di lakukan secara normal, kini harus beralih menjadi adaptasi new 
normal dimana jika sebelumnya belajar dilakukan di sekolah, sejak maret 2020 lalu semuanya dilakukan secara daring atau online.

Pembelajaran daring merupakan solusi yang digunakan untuk menunjang tetap berlangsungnya proses belajar mengajar yang kondusif di masa pandemi ini. Pembelajaran daring merupakan pembelajaran yang dilaksanakan dengan tanpa tatap muka, tetapi dengan menggunakan platform yang sudah tersedia. Menurut Putra \& Irwansyah (2020) pembelajaran daring yaitu pembelajaran yang dilakukan tanpa interaksi fisik antara guru dan peserta didik dengan proses pembelajaran yang mengeliminasi waktu dan jarak dengan menggunakan platform digital yang berbasis internet. Segala bentuk materi pembelajaran, komunikasi, dan juga tes dilakukan secara online. Menurut Elyas (2018) pendidikan daring yaitu tipe pembelajaran dimana bahan ajar yang disampaikan kepada siswa dengan menggunakan internet. Artinya proses belajar yang ditekankan pada pendidikan daring adalah dengan memakai teknologi internet untuk meningkatkan pengetahuan dan keahlian. Menurut Yunianto (2015) belajar dengan memakai teknologi internet bisa membagikan banyak informasi serta sumber belajar dan sarana yang bisa mendukung proses belajar, bahan ajar bisa diunduh serta diupload, serta tes soal untuk penilaian bisa pula dicoba. Disisi lain dengan adanya pembelajaran dengan menggunakan teknologi internet semakin memudahkan siswa dalam mengakses sumbersumber belajar dan lainnya. Demikian pula Santoso (2009) mengatakan jika proses belajar secara online bisa meningkatkan prestasi belajar. Sejalan pula dengan yang diungkapkan oleh Maudiarti (2018) jika pendidikan daring ataupun e-learning bisa digunakan kepada setiap orang, kapan saja serta dimana saja dengan memakai atribut- atribut serta sumber belajar dari teknologi digital. Sehingga dapat ditarik kesimpulan bahwa pendidikan daring adalah sistem pendidikan yang dicoba dengan tidak bertatap muka langsung, namun memakai platform yang bisa menunjang proses belajar mengajar yang dicoba walaupun dengan jarak jauh.

Tujuan dari adanya pendidikan daring yakni memberikan layanan pendidikan bermutu dalam jaringan yang bertabiat masif serta terbuka untuk menjangkau peminat ruang belajar supaya lebih banyak serta lebih luas (Sofyana \& Abdul, 2019:82). Sehingga pembelajaran dengan sistem 
daring merupakan upaya yang dilakukan dilakukan sebagai solusi agar tetap terealisasinya pembelajaran sekolah di masa pandemi.

Selama pandemi Covid-19, hampir seluruh dunia melakukan pembelajaran daring (Goldschmidt, 2020). Pemberlakuan pendidikan secara daring ini jadi pemecah masalah buat menanggulangi kesusahan dalam melakukan pendidikan tatap muka secara langsung. Tetapi, ada hambatan yang mempengaruhi efektifitas pendidikan secara daring ini, banyak yang mengeluhkan sulit sinyal, kesusahan menguasai modul, serta lain sebagainya. Kesusahan koneksi internet serta sarana belajar daring sangat dirasakan.oleh anak Sekolah Dasar yang terletak di daerah ataupun pedesaan. Koneksi internet serta tata cara pembelajaran membutuhkan bimbingan untuk dicermati. Koneksi internet wajib stabil supaya dapat tersampaikan kepada siswa dengan baik. Dan tata cara pendidikan yang efisien dibutuhkan karena mungkin siswa susah belajar terlebih bila cuma diberi modul mentah-mentah. Disini kedudukan Guru serta pendidik selaku elemen berarti dalam pengajaran diwajibkan melaksanakan migrasi besarbesaran yang belum sempat terjalin tadinya dari pembelajaran tatap muka tradisional ke pembelajaran online ataupun pembelajaran jarak jauh (Bao, 2020; Basilaia \& amp; Kvavadze, 2020), salah satunya dengan adanya. surat Edaran Departemen Pembelajaran serta Kebudayaan (Kemendikbud) Direktorat Pembelajaran Besar Nomor 1 Tahun 2020 menimpa penangkalan penyebaran Covid-19 di dunia pembelajaran. Melihat situasi yang demikian itulah Kemendikbud langsung bergerak cepat memberi intruksi kepada kepala-kepala cabang pendidikan untuk melaksanakan pembelajaran jarak jauh dan membuat skema belajar di rumah masing-masing bagi siswa.

Perkembangan teknologi informasi (TI) mempunyai pengaruh besar terhadap pergantian metode pembelajaran dalam tiap bidang. Salah satunya yakni pergantian pada bidang pembelajaran. Teknologi bisa dimanfaatkan dalam aktivitas proses belajar mengajar, yang bisa dikatakan ialah pergantian dari metode konvensional jadi ke modern. Gheytasi, Azizifar \& amp;Gowhary dalam Khusniyah serta Hakim (2019:21) mengatakan kalau sebagian riset menyimpulkan bahwa berkembangnya teknologi memberikan banyak pengaruh positif terhadap pendidikan. Dalam memenuhi kegiatan pendidikan, Internet telah dipadukan menjadi suatu perlengkapan sebagai penunjang pembelajaran (Martins, 2015). Saat ini 
seiring dengan berkembangnya digitalisasi sistem dan revolusi industri 4.0, maka solusi untuk tetap bisa menjalankan tercapainya proses belajar mengajar di masa pandemi adalah dengan pembelajaran secara daring (dalam jaringan) dari rumah masing-masing (Lestari \& Gunawan, 2020).

Sistem pembelajaran melalui daring ini dibantu dengan beberapa aplikasi yang tersedia di playstore yang dapat dengan mudah didownload. Aplikasi-aplikasi ini sangat mendukung pembelajaran daring dan menunjang aktivitas belajar mengajar di saat pandemi Covid-19, aplikasi-aplikasi tersebut diantaranya; WhatsApp, Zoom, Website Web, Edmodo dan lainlain. Sesuai dengan pendapat Gunawan et al. (2020) dalam masa pandemi kegiatan belajar dari rumah dapat dilakukan dengan menggunakan berbagai platform diantaranya WhatsApp, Moodle, Google Classroom, Email, Zoom dan lainnya. Pemerintah juga mengambil kebijakan dalam menanggulangi ketimpangan aktivitas belajar selama pandemi Covid-19 ini. Mengutip halaman resmi Kemendikbud RI, terdapat 12 media sosial ataupun aplikasi yang dapat diakses pelajar untku belajar di rumah diantaranya: Rumah belajar, Meja kita, Icando, Indonesiax, Google for education, Kelas pintar, Microsoft office 365, Quipper, Ruang guru, Sekolahmu, Zenius, Cisco webex.

Tantangan dari adanya pendidikan daring salah satunya yaitu kemampuan dalam pemakaian teknologi dari pihak pendidik ataupun partisipan didik. Dabbagh (dalam Hasanah, dkk., 2020:3) mengatakan kalau identitas siswa dalam kegiatan belajar daring ataupun secara online yaitu :

1. Kemandirian belajar masing-masing siswa menjadikan perbedaan keberhasilan belajar yang berbeda- beda.

2. Literasi terhadap teknologi: tidak hanya kemandirian terhadap aktivitas belajar, tingkatan uraian pelajar terhadap konsumsi teknologi. Yang mana pendidikan online/ daring adalah salah satu keberhasilan dari pelaksanaan pendidikan daring. Dalam pendidikan daring/ online siswa wajib melaksanakan kemampuan terhadap teknolologi yang hendak digunakan. Perlengkapan yang biasa digunakan selaku fasilitas pendidikan online/ daring yakni pc, smartphone, ataupun laptop. Pertumbuhan teknologi di masa 4. 0 ini menghasilkan banyak aplikasi ataupun fitur-fitur yang digunakan dalam menunjang fasilitas pendidikan daring/ online. 
3. Keahlian berbicara interpersonal: dalam identitas ini pelajar wajib memahami keahlian berbicara serta keahlian interpersonal selaku salah satu ketentuan keberhasilan dalam pendidikan daring. Keahlian interpersonal diperlukan untuk mempererat ikatan dan interaksi antar pelajar. Selaku makhluk sosial senantiasa memerlukan interaksi dengan orang lain, meskipun pendidikan online dilaksanakan secara mandiri. Sehingga keahlian interpersonal serta keahlian dalam komunikasi wajib senantiasa dilatih dalam kehidupan bermasyarakat.

4. Bekerjasama: menguasai serta mengenakan pendidikan interaksi serta kerja sama. Pelajar wajib mempunyai kemampuan dalam berinteraksi dengan pelajar yang lain maupun dengan dosen pada suatu forum yang sudah disediakan, sebab dalam pendidikan daring subjek nya merupakan pelajar itu sendiri. Interaksi tersebut dibutuhkan ketika pelajar menghadapi kesusahan dalam menguasai modul. Tidak hanya perihal tersebut, interaksi sangat dibutuhkan untuk melatih jiwa sosial mereka. Suapaya jiwa individualisme serta anti sosial tidak tercipta didalam diri pelajar. Dengan terdapatnya pendidikan daring pula pelajar sanggup menguasai pendidikan dengan kerja sama. Pelajar juga dilatih untuk mampu bekerjasama baik dengan sesamanya ataupun dengan berbagai sistem yang menunjang pendidikan daring.

5. Keahlian dalam belajar mandiri: salah satu ciri pendidikan daring merupakan keahlian dalam belajar mandiri. Belajar yang dilakukan secara mandiri sangat dibutuhkan dalam pendidikan daring. Sebab dalam proses pendidikan, Pelajar hendaknya mencari, menciptakan sampai dengan merumuskan sendiri tentang apa yang sudah dipelajari. "Pendidikan mandiri ialah proses dimana siswa dilibatkan secara langsung dalam mengenali apa yang dibutuhkan untuk dipelajari sehingga menjadi pemegang kendali dalam proses pendidikan" (Kirkman dalam Hasanah, 2020). Sehingga dalam belajar secara mandiri, diperlukan motivasi selaku penunjang keberhasilan proses pendidikan secara daring.

Peran orang tua atau wali murid sudah mutlak dibutuhkan dalam tumbuh kembang anak terutama dalam proses pembelajaran. Setiap anak memiliki potensi diri yang tidak terbatas, tetapi untuk menunjang potensi tersebut ada beberapa faktor yang mempengaruhinya, diantaranya adalah peran orang tua yang memiliki dampak yang luas dalam tumbuh kembang 
anak. Peran orang tua sangat penting bagi anak untuk menumbuhkan dan mengembangkan prestasi anak, tidak hanya ketika di rumah saja tetapi juga ketika anak belajar di sekolah, mungkin sebagian orang tua berpendapat ketika anak mereka belajar di sekolah, seutuhnya guru yang memiliki peran tersebut. Hal ini sesuai dengan pendapat Wardhani \& Krisnani (2020) keterlibatan orang tua sangatlah penting untuk prestasi anak di sekolah. Sehingga orang tua tetap terlibat dalam meningkatkan minat belajar anak baik di rumah maupun di sekolah. Pendidikan merupakan hal utama yang diberikan para orang tua, dengan cara memberikan pendidikan yang terbaik mulai sejak dini kepada anak-anak mereka. Sehingga orang tua sangatlah memegang peranan yang penting dalam membimbing dan membina anak dalam keseharian mereka. Kewajiban orang tua adalah menggali potensi anak dengan cara menumbuhkan suasana yang nyaman dan kondusif, sehingga tidak hanya potensi anak yang muncul tetapi juga bisa mengembangkan kecerdasan dan rasa percaya diri anak. Dalam mendampingi tumbuh kembang anak, orang tua juga harus memahami setiap tahap kebutuhan pengembangan potensi pada anak.

Pandemi Covid-19 sangatlah berdampak negatif bagi banyak sektor dalam pemerintahan, khususnya dalam sektor pendidikan. Solusi supaya tetap tercapainya pembelajaran yang kondusif adalah dengan pembelajaran daring. Namun beban yang cukup berat dirasakan oleh semua warga sekolah terutama wali murid dalam menyesuaikan pembelajaran dari rumah. Belum lagi dalam mendukung pembalajaran daring harus menggunakan beberapa platform dan juga membutuhkan jaringan internet, otomatis muncul problematika yang dihadapi semua pihak, baik dari dewan guru, wali murid dan peserta didik. Wali murid menambah peran dalam mengawasi dan mendampingi proses pembelajaran yang seharusnya dilaksanakan di sekolah dan kini beralih menjadi pembelajaran daring yang dilakukan dari rumah. Hal ini tidak mudah, karena wali murid juga harus memberikan pengertian pada anak bahwa harus tetap semangat belajar seperti sebelumnya ketika belajar di sekolah.

Berdasarkan uraian diatas, tujuan dari pengabdian ini adalah mendeskripsikan peran dari guru dan wali murid dalam pendampingan pembelajaran daring dan juga problematika-problematika yang dihadapi dalam pembelajaran tersebut. 


\section{Metode}

Metode pengabdian ini adalah kualitatif, yaitu penelitian yang menghasilkan data deskriptif berupa lisan ataupun kata-kata tertulis dari hal-hal yang diamati (Tanzeh, 2011), sehingga dalam pelaksanaan pengabdian ini, tim pengabdi masyarakat hanya mendeskripsikan problematika dalam pembelajaran daring. Pengabdian ini berlangsung selama 3 bulan, mulai dari bulan Februari sampai dengan bulan Mei, subyek dalam pengabdian ini adalah wali murid, dewan guru dan mengambil sampel 3 peserta didik MI Nurul Mun'im.

Pengabdian ini dilaksanakan dalam beberapa tahap sebagai berikut:

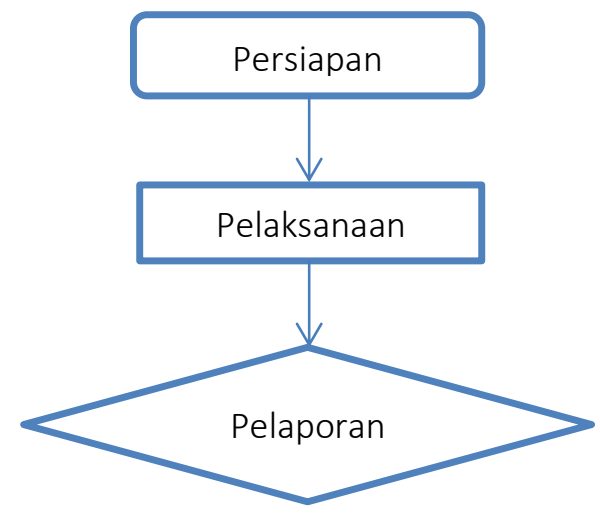

Gambar 1. Diagram tahapan pengabdian

a. Tahap persiapan

Pada awalnya tim pengabdi masyarakat meminta izin kepada Kepala Madrasah dan berkoordinasi dengan beberapa dewan guru juga berdiskusi dengan beberapa wali murid dalam hal pelaksanaan pendampingan peserta didik dalam pembelajaran daring.

b. Tahap pelaksanaan

Dalah tahapan ini, tim pengabdi masyarakat bersosialisasi dengan dewan guru tentang bagaimana proses pembelajaran daring, kemudian melakukan pendampingan terhadap beberapa peserta didik pembelajaran daring menggunakan laptop dan handpone. 


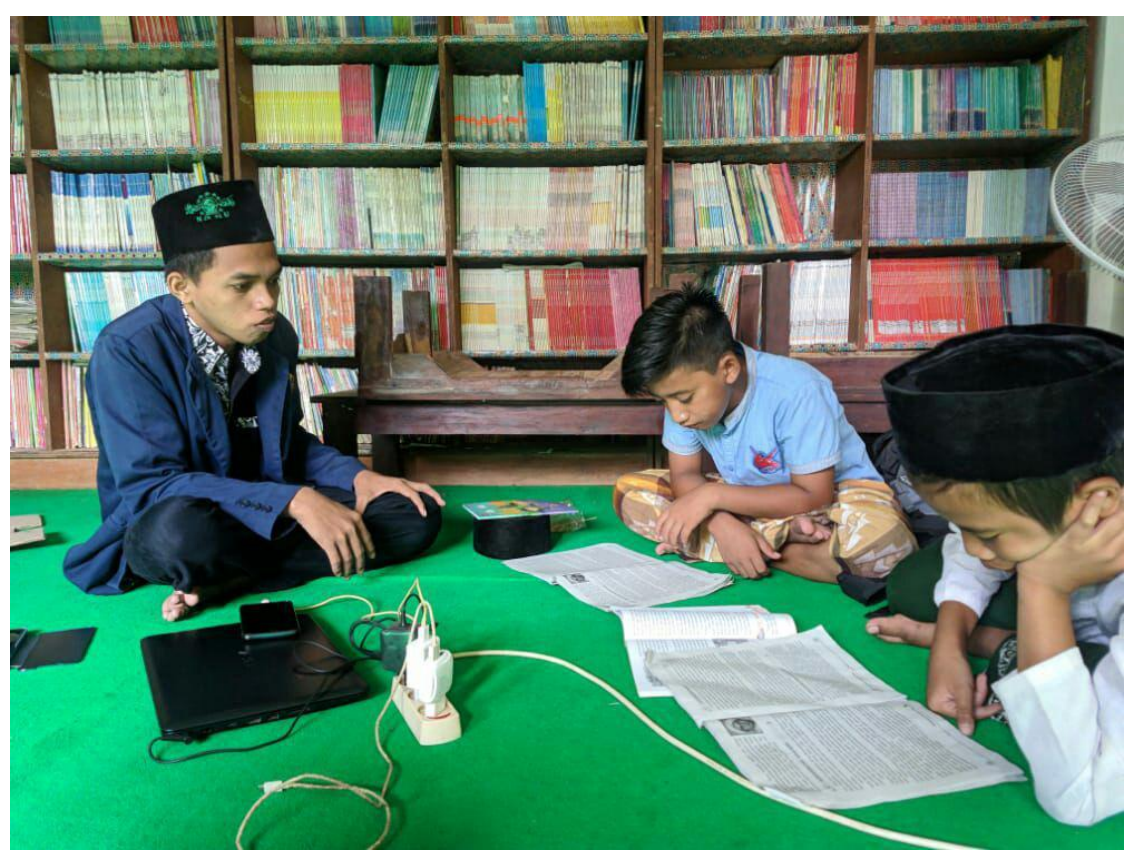

Gambar 2. Pendampingan pembelajaran daring menggunakan laptop

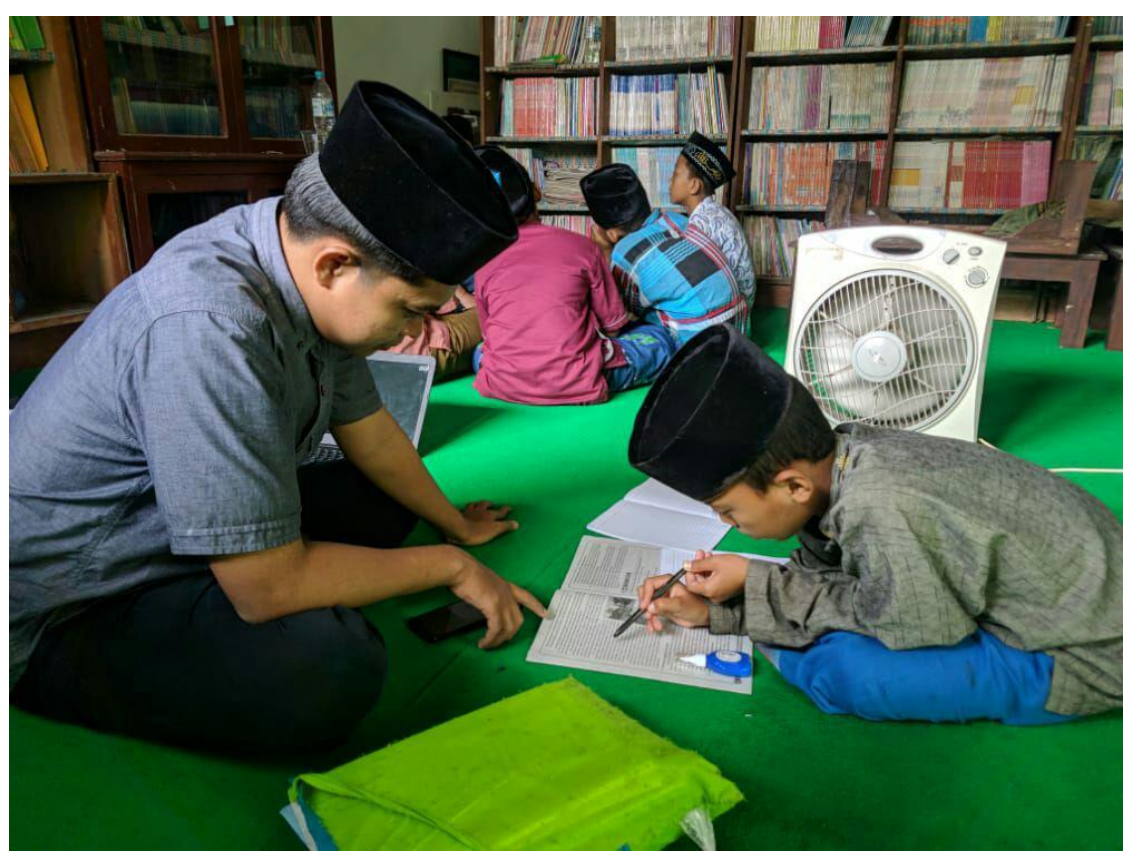

Gambar 3. Pendampingan pembelajaran daring menggunakan handphone 
c. Tahap pelaporan

Setelah melakukan pendampingan terhadap peserta didik dan juga berinteraksi terhadap beberapa dewan guru, tim pengabdi masyarakat meminta pendapat para guru tentang pembelajaran daring di masa pandemi ini.

\section{Hasil}

Dalam masa pandemi ini, banyak dewan guru yang mengimplementasikan proses pembelajaran dengan beragam cara belajar di rumah masing-masing, dari perbedaan belajar inilah tetap berbasis pembelajaran daring. Di lembaga MI Nurul Mun'im, WhatsApp group dipilih dalam kegiatan pembelajaran daring, para guru lebih memilih sistem daring dengan menggunakan WhatsApp group, dikarenakan lebih efektif dan mudah di akses untuk peserta didik dan wali murid. WhatsApp group juga dapat dijadikan kegiatan untuk memberikan pembelajaran secara online dan bisa dijadikan sarana pengiriman tugas maupun materi selama masa pandemi berlangsung. Guru menyampaikan bahwa laporan hasil pembelajaran daring dibuktikan melalui audio atau berupa voice note. Hasil pembelajaran tersebut lalu dikirim melalui WhatsApp group untuk dikumpulkan dan disimpan sebagai tugas dari peserta didik MI Nurul Mun'im.

Selama pendampingan pembelajaran daring berlangsung kami menemukan beberapa dari peserta didik kami masih belum memahami materi yang sudah dijelaskan melalui audio atau voice note. Oleh karna itu kami memberikan arahan atau solusi kepada peserta didik supaya memahami kembali dengan mengulang dengan cara memutar kembali audio ataupun voice note. Proses kegiatan pembelajaran daring merupakan suatu kegiatan pembelajaran secara online yang dijadikan sebagai pengganti dari pembelajaran offline selama masa pandemi berlangsung. Maka dari itu pihak dari lembaga menggunakan kegiatan daring tersebut untuk mencegah Covid-19.

Proses kegiatan pembelajaran daring merupakan suatu kegiatan pembelajaran secara online yang dijadikan sebagai pengganti dari pembelajaran offline selama masa pandemi berlangsung. Maka dari itu 
pihak dari lembaga menggunakan kegiatan daring tersebut untuk mencegah Covid-19.

\section{Pembahasan}

Dalam kegiatan pembelajaran daring di MI Nurul Mun'im, ada beberapa faktor-faktor yang kami temukan di antaranya:

1. Faktor Pendukung Pembelajaran Daring

Faktor pendukung yang dimaksud yaitu segala proses yang berorientasi untuk mengajak dan ikut serta dalam dukungan suatu kegiatan yang dimaksud. Didalam kegiatan pembelajaran daring yang dapat kita temukan dari faktor pendukung tersebut merupakan dampak positif selama kegiatan pembelajaran daring berlangsung. Implementasi pembelajaran daring telah dilakukan oleh pemerintah jauh sebelum adanya pandemi Covid-19 dengan diterapkannya belajar secara mandiri, akan tetapi ketika pandemi ini melanda, implementasi pembelajaran secara daring merupakan solusi yang digencarkan pemerintah untuk tetap berlangsungnya proses belajar mengajar secara efektif sehingga hal ini adalah tantangan besar yang dihadapi para dewan guru dan para peserta didik, yang menjadi kendala adalah dalam penggunaan platform tertentu yang belum dibiasakan oleh guru maupun peserta didik (Almanthari et al., 2020).

Dalam pelaksanaan pembelajaran daring membutuhkan bantuan teknologi. Teknologi pembelajaran terus mengalami perkembangan, hal ini sesuai dengan pendapat Zaharah et al. (2020) setiap elemen pendidikan dalam masa pandemi Covid-19 dituntut agar sesegera mungkin menguasai teknologi, inovasi dan meningkatkan kreativitas. Terdapat dua jenis teknologi, yang mana dua jenis tersebut yaitu technology based web learning dan technology based learning. Adapun yang termasuk dalam technology based web learning merupakan data informasi teknologi (internet, bulletin board, tele-collaboration, email). Sedangkan technology based learning pada prinsipnya terdiri dari audio informasi (voice, audio, mail telephone) dan video informasi teknologi (video text, video messaging, video tape). 
Ada beberapa faktor pendukung berjalannya kegiatan daring ini di antaranya:

a. Handphone dan jaringan internet

Handphone adalah perangkat telekomunikasi elektronik yang mempunyai kemampuan yang canggih yang bisa kita dapat dibawa kemanapun dan kapanpun selama kita membutuhkan. Salah satu fasilitas yang menunjang dalam pembelajaran daring adalah smartphone atau handphone (Noveandini \& Wulandari, 2010). Seperti halnya kegiatan daring kita dapat menggunakan handphone tersebut untuk bisa digunakan sebagai bahan pembelajaran secara jarak jauh. Begitu pula pada masa pandemi yang masih sekarang belum membaik. Oleh karena itu lembaga melakukan kebijakan yang bisa mencegah adanya penyebaran virus Covid-19 untuk melakukan kegiatan pembelajaran secara online (daring). Hal tersebut dapat membuat peserta didik untuk melakukan kegiatan pembelajaran secara online dengan menggunakan handphone atau android.

Jaringan internet adalah suatu jaringan komunikasi yang memiliki fungsi untuk menghubungkan antara satu media elektronik dengan media elektronik yang lain dengan cepat dan tepat. Patria \& Yulianto (2011) mengemukakan bahwa pembelajaran online dilaksanakan dengan menggunakan pemanfaatan teknologi khususnya jaringan internet. Adanya jaringan internet ini kita bisa melakukan kegiatakegiatan yang dapat kita butuhkan seperti halnya kita mengikuti kegiatan pembelajaran di lembaga secara online.

Maka dari itu jaringan internet ini memberi solusi yang tepat untuk kita manfaatkan dengan baik dengan adanya kegiatan pembelajaran secara online (daring) tersebut peserta didik puas dan tidak bingung lagi dalam melaksanakan kegiatan pembelajaran daring tersebut. Begitupun perlu juga di manfaatkan dengan baik dan digunakan untuk hal-hal yang bermanfaat.

b. Buku mata pelajaran

Buku mata pelajaran dipakai sebagai buku acuan yang wajib dipakai oleh madrasah yang memuat materi pembelajaran yang diberikan kepada peserta didik untuk dipelajari dan dipahami untuk 
memberikan suatu pengetahuan secara konsisten. Peserta didik akan memulai pembelajaranya dengan mempelajari buku yang sesuai dengan mata pelajarannya yang sudah diberikan oleh madrasah sesuai hari yang sudah di tentukan. Contoh pada hari selasa merupakan jadwal dari mata pelajaran PKN, maka dari itu peserta didik memulai pembelajarannya dengan mempelajari buku PKN tersebut untuk dipahami dan dimengerti. Buku mata pelajaran ini dapat mendukung dan memberikan mengoptimalkan peserta didik untuk dijadikan bahan pembelajaran. Oleh karena itu pihak madrasah memberikan buku pelajaran kepada peserta didik supaya bisa memberikan pengetahuan dan ilmu yang berguna dan bermanfaat.

c. Jangkauan sumber pembelajaran yang luas

Pembelajaran daring dengan menggunakan jaringan internet menguntungkan bagi peserta didik untuk bisa lebih menjangkau materi-materi yang luas, sesuai dengan pendapat Basa dan Hudaidah (2021) kelebihan pembelajaran daring adalah mudahnya mengakses materi-materi menggunakan jaringan internet yang tidak terbatas. Sejalan dengan hal itu, Mawardi \& Iriani (2019) juga berpendapat bahwa penyajian materi pembelajaran yang ada belum memenuhi kebutuhan belajar siswa sehingga diperlukan tambahan sumber pembelajaran konten multimedia agar pemahaman siswa lebih optimal.

d. Adanya intraksi antara guru dan wali murid dalam kegiatan daring berlangsung.

Yang dimaksud dengan interaksi disini adalah pendampingan dan pengawasan wali murid terhadap peserta didik selama proses pembelajaran berlangsung. Untuk mendukung pembelajaran daring, diperlukan koordinasi antara guru dan wali murid yang dapat berupa foto dokumentasi atau dengan video call sebagai bentuk laporan bahwa siswa benar-benar melaksanakan pembelajaran di rumah dengan baik (Wicaksono \& Rachmadyanti). Jadi selain guru memberikan materi di group WhatsApp juga ada pendampingan langsung dari wali murid di rumah sehingga proses pembelajaran daring berjalan dengan baik. Sejalan dengan hal itu Darmono (2020) 
mengemukakan bahwa wali murid berperan untuk menghubungkan informasi dari guru untuk disampaikan kepada anaknya.

e. Suasana belajar yang baru

Dengan adanya pembelajaran daring yang bisa diakses melalui online dan bisa dilakukan dari rumah, dampak positifnya yaitu peserta didik bisa merasakan suasana baru dalam belajar sehingga tidak hanya monoton di dalam kelas sekolah saja, hal ini sesuai dengan pendapat Yulianto \& Nugraheni (2021) salah satu sisi positif dari pembelajaran daring adalah peserta didik lebih fleksibel dan semakin banyak waktu bersama orang tuanya saat belajar di rumah.

f. Pembelajaran dapat dilakukan dimana saja dan kapan saja

Pembelajaran daring bisa dilakukan tidak hanya dari rumah, tetapi bisa dilakukan dimana saja selama terdapat media seperti hp atau yang lainnya, terdapat aplikasi yang mendukung pembelajaran dan selama tersedianya jaringan internet, sesuai dengan pendapat Ainur Risalah et al. (2020) pembelajaran daring lebih fleksibel karena bisa dilakukan dimana saja dan kapan saja. Sejalan dengan hal itu menurut Hadisi dan Muna (2015) salah satu keuntungan pembelajaran daring adalah fleksibilitas tempat, yang mana selama ada alat komunikasi yang tetap terhubung dengan jaringan internet, maka materi dapat diunduh kapan saja.

\section{Faktor Penghambat Pembelajaran Daring}

Faktor Penghambat yang dimaksud adalah faktor yang sifatnya menghambat jalannya suatu kegiatan. Dimasa pandemi ini kita sering mengalami suatu hambatan yang bisa membuat orang tidak melakukan aktifitas seperti biasanya, mulai dari kalangan pelajar dari tingkat MI/SD hingga perguruan tinggi. Oleh karena itu madrasah memilih kegiatan pembelajaran daring ini supaya peserta didik tetap aktif dalam melakukan kegiatan pembelajaran online meskipun ada beberapa faktor yang dapat menghambat proses kegiatan pembelajaran daring tersebut.

Adapun faktor-faktor penghambat atau kendala yang menyebabkan kegiatan pembelajaran daring terhambat diantaranya: 
a. Guru tidak bisa menjelaskan secara maksimal karena perubahan cara dan sistem pembelajaran (daring).

Dengan sistem pembelajaran daring, jelas tidak sama seperti sistem sebelumnya dimana guru dapat berinteraksi langsung dengan murid di kelas, juga dapat mengontrol langsung peserta didik dengan maksimal, berbeda dengan pembelajaran di masa pandemi ini, semua harus menggunakan pembelajaran daring dengan menggunakan teknologi informasi yang mana membuat pembelajaran kurang maksimal. Dalam pembelajaran daring, guru dituntut untuk menguasai teknologi informasi supaya pembelajaran bisa dilakukan dengan efektif (Nugraha et. al., 2020).

Dalam pembelajaran daring, belum maksimalnya sarana pendukung dalam mengakses gambar, video, grafik dan lain-lain, membuat peserta didik merasa jenuh (Putra, 2020). Sehingga guru juga dituntut untuk memberikan pemahaman cara mengakses materi-materi dengan baik dan memberikan pembelajaran yang membuat peserta didik bersemangat belajar dan tidak merasa bosan.

b. Keterbatasan alat media bagi wali murid atau peserta didik.

Kita tahu bahwa di masa pandemi ini semua pembelajaran menggunakan sistem daring. Oleh karena itu, perlu adanya alat media atau komunikasi sebagai alat penunjang, yang dimiliki wali murid atau peserta didik untuk mengikuti kegiatan pembelajaran daring. Akan tetapi dalam kenyataannya tidak semua wali murid atau peserta didik mempunyai media seperti HP/laptop. Salah satu kendala dalam pembelajaran daring yang dialamai peserta didik adalah tidak tersedianya $\mathrm{Hp}$ atau alat teknologi lainnya (Proborini, 2021).

Hal ini perlu kita evaluasi agar peserta didik tetap bisa mengikuti pembelajaran seperti tetep belajar di sekolah bagi peserta didik yang alat medianya terbatas. Beberapa dari sebagian wali murid mengeluh akan alat media seperti $\mathrm{Hp}$ yang kurang mendukung dan tidak bisa mendengarkan pembahasan melalui audio ataupun voice note. 
c. Kurangnya motivasi belajar peserta didik

Penyebab kurangnya motivasi belajar peserta didik adalah adanya pembelajaran daring yang dilakukan dengan jarak jauh sehingga tidak bisa berinteraksi dengan sesama peserta didik maka menimbulkan rasa bosan dalam proses pembelajaran. Hal ini sesuai dengan pendapat Rimbarizki (2017) pada pembelajaran daring peserta didik bisa menjadi kurang aktif dalam belajar sehingga mengakibatkan pembelajaran yang menjenuhkan, yang nantinya membuat peserta didik memperoleh ketidakmajuan dalam hasil belajar, oleh karena itu diperlukan pendorong agar peserta didik semangat lagi untuk belajar dan berprestasi. Sejalan dengan hal itu Anugrahana (2020) berpendapat bahwa peserta didik yang mengalami kebosanan ketika pembelajaran daring membuat guru harus memikirkan strategi untuk menghilangkan kebosanan mereka dengan membuat metode pembelajaran yang lain.

Dengan tidak adanya interaksi secara langsung antara guru dan peserta didik, terkadang membuat peserta didik lalai untuk menyelesaikan tugas-tugasnya, atau adanya suatu kendala sehingga tidak bisa mengumpulkan tugas lewat daring, hal ini sesuai dengan pendapat Utami et. al., (2020) siswa mengalami kendala dalam mengumpulkan tugas di e-learning dikarenakan belum bisa mengontrol belajar daring dari rumah.

d. Keterbatasan kouta internet

Salah satu faktor penghambat lainnya yaitu keterbatasan kouta internet yang mana ini sangat diperlukan bagi peserta didik demi lancarnya kegiatan pembelajaran daring, kouta internet ini di perlukan untuk mengakses media sosial seperti WA yang mana juga digunakan untuk pembelajaran daring saat ini. Perlu kita ketahui bahwa harga kuota sangat mahal dan juga di sisi lain semua pekerjaan baik itu bisnis, buruh dsb kurang berjalan dengan maksimal dikarenakan adanya Covid-19 ini. Diperlukan perbaikanperbaikan yang dilakukan oleh pemerintah dalam menunjang pembelajaran daring dengan menfasilitasi sarana prasarana salah satunya adalah penyediaan kuota internet dengan merata (Wulandari et. al., 2020). Maka dari itu hendaknya pemerintah 
memberikan subsidi berupa kuota internet yang diberikan kepada pihak madrasah untuk di berikan kepada peserta didik.

e. Terbatasnya pengawasan secara langsung

Tantangan yang muncul akibat dari pembelajaran jarak jauh adalah guru tidak bisa mengawasi peserta didik secara langsung, sehingga belum tentu peserta didik benar-benar fokus dalam pembelajaran. Hal ini sesuai dengan pendapat Szpunar et. al., (2013) lokasi guru dan peserta didik yang terpisah menyebabkan guru tidak bisa mengawasi siswa secaea langsung selama proses pembelajaran, jadi tidak ada jaminan bahwa peserta didik bersungguh-sungguh mengikuti pembelajaran.

f. Peran Wali murid

Di tengah kesibukannya, beban berat dirasakan oleh orang tua atau wali murid yang mana dituntut mampu meluangkan waktu untuk mendampingi, mengawasi anak dalam pembelajaran daring. Sehingga wali murid juga dituntut untuk memahami materi-materi yang disampaikan oleh guru, jika wali murid tidak mampu memahaminya, maka akan berakibat anak mengalami kesulitan dalam memahami materi-materi tersebut. Utami (2020) juga berpendapat bahwa keterlibatan atau peran orang tua sangatlah penting agar anak bisa berprestasi di sekolah. Apalagi untuk anak usia $\mathrm{Ml}$ yang memang masih membutuhkan penadampingan orang tua dalam pembelajaran daring.

\section{Kesimpulan}

Dari paparan diatas serta didukung oleh pendapat para ahli, maka dapat ditarik beberapa kesimpulan yaitu :

1. Pendidikan daring merupakan salah satu pemecahan untuk menerapkan social distancing guna menghindari mata rantai penyebaran wabah Covid-19. Sebab pendidikan daring ialah pendidikan yang dicoba secara online dengan jarak jauh ataupun pendidikan yang dilakukan oleh peserta didik dimanapun serta kapanpun pada saat yang diperlukan. Sehingga bisa menjauhi 
kerumunan yang sehingga menjadi salah satu metode untuk menerapkan social distancing.

2. Dalam pendidikan daring memerlukan fasilitas serta prasarana yang mencukupi, seperti laptop, pc, smartphone serta jaringan internet. Perihal seperti itu yang menjadi salah satu tantangan untuk melaksanakan pendidikan daring. Tetapi meskipun tidak semua siswa memiliki laptop ataupun pc, sebagian besar dari mereka mempunyai smartphone

3. Pembelajaran daring membuat siswa menjadi lebih mandiri, sebab lebih menekankan student centered, sehingga mereka lebih berani untuk mengemukakan komentar serta ide- idenya. Dan pemerintah juga sudah menyediakan sebagian platform yang dapat digunakan peserta didik untuk belajar.

4. Guru harus membuat suasana pembelajaran daring menjadi lebih menyenangkan supaya peserta didik tetap bersemangat belajar dan tidak merasa bosan dan juga harus menguasai tekonologi informasi sebagai penunjang utama pembelajaran daring agar peserta didik mampu memahami semua materi yang diajarkan.

5. Peran wali murid sangatlah penting dalam pembelajaran daring ini, mengingat anak usia $\mathrm{MI}$ masih belum bisa mandiri dalam hal belajar dan sangat membutuhkan bimbingan orang tuanya, apalagi dengan menggunakan teknologi informasi dan jaringan internet penunjang pembelajaran daring.

Adapun beberapa jenis aplikasi yang paling sering dimanfaatkan dalam menjalankan proses pembelajaran daring adalah sebagai berikut (1) Zoom, (2) Classroom, (3) WhatsApp group.

\section{Pengakuan}

Kami tim pengabdi masyarakat mengucapkan terimakasih kepada pimpinan Fakultas Agama Islam dan LPPM Universitas Nurul Jadid atas kesempatan melaksanakan pengabdian ini, ucapan terimakasih juga kami sampaikan kepada Kepala MI Nurul Mun'im dan jajarannya yang telah memberikan ijin serta membantu kami untuk melakukan pengabdian masyarakat dengan judul "pendampingan guru MI Nurul Mun'im dalam mengoptimalkan peran wali murid dalam pembelajaran daring. 


\section{Referensi}

Almanthari, A., Maulina, S., \& Bruce, S. (2020). Secondary School Mathematics Teachers' Views on E-learning Implementation Barriers during the Covid-19 Pandemic: The Case of Indonesia. Eurasia Journal of Mathematics, Science and Technology Education, 16(7).

Anugrahana, A. (2020). Hambatan, Solusi dan Harapan: Pembelajaran Daring Selama Masa Pandemi Covid-19 Oleh Guru Sekolah Dasar. Scholaria: Jurnal Pendidikan dan Kebudayaan, 10(3), 282-289.

Darmono, A. (2020) Best Paractice Pembelajaran Daring di Madrasah Ibtidaiyah pada Masa Pandemi Covid-19. Kurikula, Jurnal Pendidikan, 5(1), 47.

Dewi, W.A.F. (2020). Dampak Covid-19 terhadap Implementasi Pembelajaran Daring Di Sekolah Dasar. Jurnal IImu Pendidikan, 2(1), 5561.

Elyas, H. A. (2018). Penggunaan Model Pembelajaran E Learning dalam Meningkatkan Kualitas Pembelajaran. Jurnal Warta. Vol. 56, 1829-7463.

Goldschmidt, K. (2020). The COVID-19 Pandemic: Technology Use to Support the Wellbeing of Children. Journal of Pediatric Nursing.

Gunawan, G., Suranti, N. M. Y., \& Fathoroni, F. (2020). Variations of Models and Learning Platforms for Prospective Teachers During the COVID-19 Pandemic Period. Indonesian Journal of Teacher Education, 1(2), 61-70.

Hadisi, L., \& Muna, W. (2015). Pengelolaan Teknologi Informasi Dalam Menciptakan Model Inovasi Pembelajaran. Jurnal Al-Ta'dib, 8(1), 17-40.

Hasanah, dkk. (2020). Analisis Aktivitas Belajar Daring Mahasiswa Pada Pandemi COVID-19. Jurnal Pendidikan. Vol.1(1).

Kusniyah \& Hakim, L . (2019). Efektifitas Pembelajaran Berbasis Daring: Sebuah Bukti pada Pembelajaran Bahasa Inggris. Jurnal Pemikiran dan Penelitian Pendidikan, Vol.17(1).

Lestari \& Gunawan. (2020). The Impact Of Covid-19 Pandemic On Learning Implementation Of Primary And Secondary School Levels. Indonesian journal of elementary and childhood education, 1(2), 58-63. 
Martins, M. de L. (2015). How to Effectively Integrate Technology in the Foreign Language.

Maudiarti, S. (2018). Penerapan E- Learning Di Perguruan Tinggi. Jurnal Perspektif Ilmu Pendidikan. Vol.32(1).

Mawardi, and Tuti Iriani. 2019. "Pengembangan Media Pembelajaran Berbasis Multimedia Pada Mata Kuliah Kompetensi Pembelajaran Pokok Materi Keterampilan Dasar Mengajar." Jurnal Pendidikan Teknik Sipil, 8(1): 24-30.

Noveandini, R., \& Wulandari, M. S. (2010). Pemanfaatan Media Pembelajaran secara Online (E-Learning) Bagi Wanita Karir dalam Upaya Meningkatkan Efektivitas dan Fleksibilitas Pemantauan Kegiatan Belajar Anak Siswa/i Sekolah Dasar. Seminar Nasional Aplikasi Tekonologi Informasi (SNATI).

Nugraha, S. A., Sudiatmi, T., \& Suswandari, M. (2020). Studi Pengaruh Daring Learning Terhadap Hasil Belajar Matematika Kelas IV. Jurnal Inovasi Penelitian, 1(3), 265-276.

Patria, L., \& Yulianto, K. (2011). Pemanfaatan Facebook untuk Menunjang Kegiatan Belajar Mengajar Online Secara Mandiri. Repository UT, 1(1).

Proborini, E. (2021). Evaluasi Pembelajaran Matematika Secara Daring Pada Siswa Kelas VI SD Karangturi. Intelligentes Jurnal Pendidikan Fisika dan Sains, 2.

Putra, R. S., \& Irwansyah, I. (2020). Media Komunikasi Digital, Efektif namun tidak Efisien, Studi Media Richness Theory dalam Pembelajaran Jarak Jauh Berbasis Teknologi di Masa Pandemi. Global Komunika: Jurnal Ilmu Sosial dan Ilmu Politik, 1(2), 1-13.

Rimbarizki, R. (2017) Penerapan Pembelajaran Daring Kombinasi dalam Meningkatkan Motivasi Belajar Peserta Didik Paket C Vokasi di Pusat Kegiatan Belajar Masyarakat (PKBM) Pionner Karanganyar. J+PLUS UNESA, 6(2).

Santoso. E. (2009). Pengaruh pembelajaran online terhadap prestasi belajar kimi ditinjau dari kemampuan awal siswa. Tesis. Universitas Sebelas Maret Surakarta. 
Sofyana \& Abdul. 2019. Pembelajaran Daring Kombinasi Berbasis WhatsApp Pada Kelas Karyawan Prodi Teknik Informatika Universitas PGRI Madiun. Jurnal Nasional Pendidikan Teknik Informatika. Vol.8(1), 81-86.

Szpunar, K. K., Moulton, S. T., \& Schacter, D. L. (2013). Mind wandering and education: From the classroom to online learning. Frontiers in Psychology.

Surat Edaran Kementerian Pendidikan dan Kebudayaan (Kemendikbud) Direktorat Pendidikan Tinggi No. 1 Tahun 2020

Tanzeh, A. (2011). Metodologi Penelitian Praktis. Yogyakarta: Teras.

Utami, E. (2020). Kendala dan Peran Orangtua dalam Pembelajaran Daring Pada Masa Pandemi Covid-19. Prosiding Seminar Nasional Pascasarjana.

Utami, Y. P., Alan, D., \& Cahyono, D. (2020). Study At Home : Analisis Kesulitan Belajar. Jurnal IImiah Matematika Realistik (JI-MR), 1(1), 2026.

Wardhani, T. Z., \& Krisnani, H. (2020). Optimalisasi Peran Pengawasan Orang Tua dalam Pelaksanaan Sekolah Online di Masa Pandemi Covid-19. Prosiding Penelitian \& Pengabdian Kepada Masyarakat. 7(1), 48-59.

Wicaksono, V. D., \& Rachmadyanti, P. (2017). Pembelajaran Blended Learning melalui Google Classroom di Sekolah Dasar. Seminar Nasional Pendidikan PGSD UMS \& HDPGSDI Wilayah Timur, 513-521.

Wuladari, M. A., Arga, H. S., et. al., (2020). Analisis Pembelajaran "Daring" Pada Guru Sekolah Dasar Di Era Covid-19. Jurnal IImiah P2M STKIP Siliwangi P2M STKIP Siliwangi, 7(2), 164-168.

Yulianto, D. \& Nugraheni, A. S. (2021). Efektivitas Pembelajaran Daring dalam Pembelajaran Bahasa Indonesia. Jurnal Pendidikan Teknologi Informasi. 1(1), 33-42.

Yunianto. A. R. (2015). Implementasi e learning berbasis kelase sebagai sumber belajar. Skripsi. Universitas Negeri Semarang.

Zaharah, Z., Kirilova, G. I., \& Windarti, A. (2020). Impact of Corona Virus Outbreak Towards Teaching and Learning Activities in Indonesia. SALAM: Jurnal Sosial dan Budaya Syar-i, 7(3), 269-282. 